\title{
Optical sciences and engineering programs at the Optical Sciences Center
}

\section{Richard Shoemaker}

Richard Shoemaker, "Optical sciences and engineering programs at the Optical Sciences Center," Proc. SPIE 9663, Eighth International Topical Meeting on Education and Training in Optics and Photonics, 966306 (6 October 2003); doi: 10.1117/12.2208374

SPIE Event: Eighth International Topical Meeting on Education and Training in Optics and Photonics, 2003, Tucson, Arizona, United States 


\title{
Optical sciences and engineering programs at the Optical Sciences Center
}

\author{
Richard Shoemaker \\ University of Arizona, Optical Sciences Center, Tucson, Arizona 85721-0094 \\ telephone: (520)621-2825; fax:(520)621-6778; e-mail: shoemaker@optics.arizona.edu
}

\begin{abstract}
The B.S., M.S., Ph.D., and distance learning programs at the University of Arizona's Optical Sciences Center have all undergone significant changes during the last two years. The rationale behind these program and curriculum changes are discussed, particularly for the undergraduate program, which recently received ABET accreditation.

(C)2003 Optical Society of America

OCIS codes: (000.2060) Education; (350.4600) Optical engineering
\end{abstract}

The Optical Sciences Center at the University of Arizona offers B.S., M.S., and Ph.D degree programs in optical sciences and engineering, as well as distance learning courses, and a Professional Graduate Certificate in Optical Sciences. In the last two years, these programs have all undergone significant changes in response to changing student needs and the ongoing expansion of optics.

At the undergraduate level, our B.S. program, while still being administered at the department level by Optical Sciences, has been transferred into the College of Engineering and Mines. At the same time, the course of study for this degree was enhanced with new and revised course offerings, and the name of the degree changed to Bachelor of Science in Optical Sciences and Engineering. The placement of the program in engineering has yielded number of benefits, including enhanced recruitment of new students and participation in engineering activities. The major effect of the program transfer, however, has been that we were able to obtain ABET accreditation of the B.S. degree program. Despite the significant time and effort involved in initially obtaining this accreditation and the ongoing effort required to maintain it, we believe that this accreditation is a significant benefit to the program. In particular, it puts the program on an equal footing with the university's other engineering programs, which helps us in competing for the best freshman engineering students. It has also caused us to focus more clearly on defining the objectives of the program, and on continuing to enhance and coordinate our lecture and laboratory course offerings.

Since 1986, Optical Sciences has offered two or three of our graduate courses per semester on video. These courses are available over the web, on CD-ROM, or by video tape either through NTU (National Technological University), or through the University of Arizona's Extended University. A significant number of our M.S. students are currently out in the workforce, and these video course offerings allow them to complete most of their coursework while remaining at their job. They then need only spend one semester in residence at the university (a UA requirement) to finish their degree work. However, for some people, spending even a semester away from their job is not possible. Although they can still take individual courses by video, they have been quite eager to find a way of receiving some formal recognition for the coursework that they do take. To fulfill this need, we began offering a Professional Graduate Certificate in Optical Sciences in fall 2002. To receive the certificate, students need only to satisfactorily complete five 3-unit graduate courses in Optical Sciences. No on-campus residency or laboratory courses are required.

Our Ph.D. program has always had, as one of its primary objectives, providing every student with a broad education across all areas of optics. Our primary vehicle for achieving this broad coverage is a set of core courses. Although these courses are not required, students usually take them as their academic coursework during their first two years here, because they need to have mastered the material in them in order to pass our comprehensive exam, which is normally taken about two years into the program. For students who join research groups working in some areas of quantum optics, however, this presents a problem, because they need a substantial amount of graduate coursework in quantum and optical physics to even get started effectively in their research program. To address this problem, Optical Sciences has instituted a second core course track which allows students to concentrate their coursework in the quantum area during their first two years, and then take courses covering the other areas of optics in later years of their program.

Eighth International Topical Meeting on Education and Training in Optics and Photonics,

edited by Barry L. Shoop, Grover Swartzlander Jr., Proc. of SPIE Vol. 9663, 966306

(C) 2003 SPIE, OSA, ICO · doi: 10.1117/12.2208374

Proc. of SPIE Vol. $9663966306-1$ 